Documentário - Sob a Pata do Boi

Diretor - Márcio Isensee e Sá

Roteirista - Juliana Tinoco

País - Brasil

Gênero - Jornalismo investigativo

Produtor Executivo - Bernardo Câmara

Argumento Eduardo - Pegurier e Paulo Barreto

Montagem - Fred Rahal Mauro

Realização - O Eco, site de jornalismo ambiental e do Imazon (Instituto do Homem e Meio Ambiente da Amazônia)

Tema - Direitos Humanos, Questões sociais e Meio Ambiente Fotografia - Fábio Nascimento

Ano - 2018

\title{
SOB A PATA DO BOI
}

\section{Maurício Reis Viana Filho'}

SOB A PATA DO BOI é um documentário de média metragem (49 minutos), que apresenta a história de como o impacto da pecuária causou o desaparecimento de um território do tamanho da França em plena Amazônia, maior floresta tropical do mundo. Salienta que $66 \%$ deste território virou pastagem para cerca de 85 milhões de cabeças de gado. Em 1970, quando o processo de desmatamento foi iniciado, o rebanho era um décimo deste tamanho e a floresta estava pouco afetada.

Neste período, a pecuária transformou-se em bandeira econômica e cultural, possibilitando a eleição de políticos muito poderosos, que passaram a defender a pecuária nesta região. A força da bancada ruralista que se beneficiava com o não cumprimento das leis era muito grande, com raras exceções, alguns fazendeiros conscientes 
afirmavam que seria possível produzir sem desmatar. Tal processo de ocupação através da pecuária, trouxe grandes mudanças culturais à região, afetando os usos e costumes da população amazônica. Rodeios passaram a ser a atração principal, trazendo consigo vestuário semelhante a roupas de cowboys americanos. $\mathrm{Na}$ área econômica o lucro era alto e o custo de produção muito baixo.

O documentário salienta que esta atividade foi incentivada pelo governo federal com o pretexto de que a Amazônia fosse habitada, atraindo milhares de fazendeiros de todas as partes do país para a região. O lema era "ocupar para não perder".

Em 2009, os frigoríficos e supermercados de todo o Brasil foram flagrados comprando carne proveniente do desmatamento. Podemos afirmar que este foi o ano do início da mudança, pois o Ministério Público passou a atuar de forma mais efetiva, propondo um Termo de Ajustamento de Conduta (TAC), forçando os frigoríficos e mercados da região a não comprarem gado das fazendas que faziam desmatamento ilegal. Esta iniciativa ainda não significou que a situação teria sido resolvida, pois ainda assim fazendeiros/empresários davam um jeito de burlar a fiscalização, usando o famoso "jeitinho brasileiro".

"Sob a pata do Boi" recebeu a Menção Honrosa na $7^{a}$ Mostra Ecofalante, assim como o prêmio One Hour Award no Fredd Festival da França.

O documentário tem o objetivo principal de alertar o governo e a população sobre a situação de catástrofe que o desmatamento está ocasionando na Amazônia. Para ratificar este alerta, sabe-se que só em 2017,20\% da região amazônica já havia sido devastada e 2/3 virado pasto. Além de abordar temas como o desmatamento, pontua também o 
comércio do boi clandestino, o trabalho escravo, a invasão biológica, a indústria da carne e a bancada ruralista.

Trailer: https://www.youtube.com/watch?v=fMwfsILKW70

Questões para reflexão:

1 - Um dos pontos fundamentais para os habitantes da região sudeste são os rios alados oriundos da Amazônia, que ajudam a suprir esta região de água mantendo as temperaturas em níveis suportáveis. Como a população vai sobreviver sem eles?

2 - Qual a sua avaliação da situação atual da Amazônia frente a uma provável extinção?

3 - Como enfrentar a ganância dos exploradores da Amazônia que promovem o desmatamento, o trabalho escravo, o comércio ilegal do gado dentre outros? 